\title{
ORGANISATION POLITICS - AN IMPORTANT CAUSE FOR TURNOVER DECISION IN CONTEXT OF CHENNAI BANKING SECTOR
}

\author{
K.R.Sowmya', Dr.N.Panchanatham ${ }^{2}$ \\ ${ }^{1}$ Research Scholar,Bharathiyar University,Coimbatore,India. \\ ${ }^{2}$ Research Supervisor, Head-Department of Management Studies, Annamalai University, Chidambaram, India \\ E-mail: 'saumiyaa@gmail.com
}

\begin{abstract}
The employment culture is changing in Chennai. It is now relatively common to change jobs frequently, rather than to grow with one company throughout the employment life. This kind of voluntary turnover directly affects the performance of the organization. So now all organizations are highly concerned to keep their valuable employees. Each day completed by an employee is an investment to an organization; to leave before the full term is to get no return on the investment. As banking is one of the vital service industry for any country and performing a number of roles in the economy, so it has been chosen by the researchers for this study. Like all other industries, banking sector in our country is also facing the same employee turnover problem. It is needless to say, healthy banking system and healthy economies seem to go together. In order to ensure that, banking sectors should focus on the factors, which are primarily responsible for employees leaving the organization. This paper mainly tries to focus on organization politics as perceived reason of employees of financial sector for leaving decision from their existing organizations.
\end{abstract}

Key words: Employee turnover, Organisation Politics, exit interview, WAS, MSRI.

\section{INTRODUCTION}

Many companies are floundering today in their attempts to improve employee retention because they have placed the responsibility for it in the hands of human resources instead of the managers (Leigh Branham, 1997). Most employees make a number of transitions between jobs during their working lives. These may include both job changes within a single employer and leaving one firm to take a job to another firm. In either case, there are usually the intention to grow and increase in skills, responsibility, and remuneration, and/or improve the "fit" between employee skills and desires and job requirements (Fisher, 2004). Each day completed by an employee is an investment; to leave before the full term is to get no return on the investment (Bennisonn, and Casson, 1984). The reason behind choosing banking sector for this study is, it plays an important role in our economy. Such institutions play a pivotal role in capital formation and stimulate the level of industrialization, poverty alleviation and human development. In a sense, healthy banks and healthy economies seem to go together (Faruk, Kashem, 2005). And a healthy banking system depends on the performance of sound personnel. In order to make sure that their employees are good performer they have to know first, the reasons of dissatisfaction and also the reasons of leaving organization as a dissatisfied employee.

There can be many different reasons for taking decisions regarding staying or not to staying with an organization. The loss of an organization's employee can be divided into three broad groups, induction crises, natural wastage, and retirement (Bennisonn, and Casson,
1984). The reason for the induction crisis can be found in jobs not fulfilling employees' expectations. And it happens within

very short period of time. There is a strongly held belief that the rate of natural wastage responds to the level of morale within the organization. This is broadly true but there is an overriding factor that operates first: the level of vacancies in the labour market for the occupation under study is a much more important variable. Retirement can be predicted with a reasonable degree of accuracy. Retirement rules are usually based on age or lengths of service or a combination of both (Bennisonn, and Casson, 1984).

Talented workers want to feel they are being paid comparably to what other companies pay for similar work in the industry. Equity Theory recognizes that individuals are concerned not only with the absolute amount of rewards for their efforts but also with the relationship of this amout to what others receive (Robbins, 1999). They also care about being paid equitably with others in similar positions making comparable contributions. When these two conditions exist along with interesting and meaningful work, acceptable working conditions and good management practices, the prospect of making a little more money in an another organization where these softer factors are unknown is usually not enough to pull the employee away (Branham, 1997).

Although many companies use contract employees to address fluctuations in business, working side by side with someone who is making twice the rate of pay without any commitment or loyalty to the company can be a real morale killer (Branham, 1997). 
Keeping good employees has more to do with how organization manages than what they pay. They stay or leave sometimes based on their relationship with their manager and their opportunity to both contribute and advance in their job. One recent study showed that 50 percent of the typical employee's job satisfaction is determined by the quality of his/her relationship with the manager.

Reducing turnover also starts with commitment of top executives. (Branham, 1997).

Work environment is another important factor, which has influence on job retention. Study found that politicsfree work environment is significantly correlated to job satisfaction of employees (Pahik and Pesonjee, 1997). Mayes and Allen (1977) defined organizational politics as, "the management of influence to obtain ends not sanctioned by the organization or to obtain sanctioned ends through non-sanctioned influence".

Current thinking suggests that organizations should aim for an optimal rate of turnover rather than the lowest possible rate. One scholar suggests that the optimal rate occurs where the curve of turnover costs crosses the curve of retention costs. So organization can reduce turnover, but only by incurring retention costs, such as higher salary, better benefits, quality-of work-life and development programs, and so on (Fisher, Schoenfeldt, and Shaw, 2004). In addition, employees should give opportunities to fulfill their increasing demand, a balance between work and family life.

Again, employment turnover costs in many organizations are very high and can significantly affect the financial performance of an organization. It is possible, though not easy, to put figure on these costs to estimate the actual dollar loss from departure of an employee (Cascio, 1991). Turnover costs like direct- include recruitment, selection, and training of new personnel, which process takes much time and also expenses. Turnover costs like indirect include such things as increased workloads and overtime expenses for coworkers, as well as reduced productivity associated with low employee morale. This situation might lead one to believe that all turnover is dysfunctional and that the lowest possible rate of voluntary turnover would be best. However, this is not necessarily true. Turnover also has benefits. An organization with a turnover rate that is too low may become stagnant and hidebound, lack of opportunities for employees to move up, and retain poor performers it would be better off without (Fisher, 2004). Organization need to calculate cost and benefits of voluntary turnover (Appendix-I) and balance with the organizations overall strategy.

\section{RESEARCH OBJECTIVES}

The purpose of this study is to find out the perceived significant causes of leaving of employees from different management hierarchy in the existing financial institutions of Chennai and its probable solutions. The study has identified:

- Perceived reasons of employees' leaving.

- Perceived factors which motivate employees to continue in the current organizations.

\section{RESEARCH METHOD}

\section{A. Sources of data}

Both primary and secondary data have been used for the purpose of this study. To collect primary data a questionnaire was designed in the light of the objectives of the study. Employees from different managerial levels from different banks were asked to fulfill the questionnaire. Secondary data were collected from available books, publications, research studies, journals, articles, and websites. Most of the questions included in the questionnaire are taken from (Fisher, D. C., Achoenfeldt, F. L., and Shaw, B.J.,2004). A total of 21 questions/factors (close ended) were developed in the light of two views. The first one (Appendix-I) consists of 10 statements about why employees leave an organization. Here respondents were asked to rank these 10 factors according to their perceived importance. The second one (Appendix-I) consists of 11 statements about why employees want to stay or like to work with the existing organization. A 5-point Likert Scale (strongly agree to strongly disagree) was used for these 11 questions/factors.

\section{B. Sample Size and Location}

The sample of the study covers the employees from banking sector. A sample of 100 executives ( $62 \%$ male and $38 \%$ female) selected purposively from different levels (Table-1) from 9 Private banks (Table-2).

Table 1. Samples in Terms of Management Levels and Gender

\begin{tabular}{|l|l|l|l|}
\hline $\begin{array}{l}\text { Different } \\
\text { Levels }\end{array}$ & $\begin{array}{l}\text { No. of } \\
\text { sample }\end{array}$ & Male & Female \\
\hline Top & 21 & 19 & 2 \\
\hline Mid & 54 & 36 & 18 \\
\hline Entry & 25 & 7 & 18 \\
\hline Total & 100 & 62 & 38 \\
\hline
\end{tabular}

Source: primary source 
Table 2. Name of Institutions and Number of Samples

\begin{tabular}{|l|l|l|l|l|}
\hline SI.No & $\begin{array}{l}\text { Name of } \\
\text { Institution }\end{array}$ & $\begin{array}{l}\text { No Of } \\
\text { Samples }\end{array}$ & Male & Female \\
\hline 1 & $\begin{array}{l}\text { City Union } \\
\text { Bank }\end{array}$ & 14 & 9 & 5 \\
\hline 2 & HDFC Bank & 8 & 5 & 3 \\
\hline 3 & ICICI Bank & 6 & 4 & 2 \\
\hline 4 & $\begin{array}{l}\text { South Indian } \\
\text { Bank }\end{array}$ & 18 & 10 & 8 \\
\hline 5 & Axis Bank & 12 & 7 & 5 \\
\hline 6 & $\begin{array}{l}\text { Karur Vysya } \\
\text { Bank }\end{array}$ & 10 & 5 & 4 \\
\hline 7 & $\begin{array}{l}\text { Lakshmi } \\
\text { Vilas Bank }\end{array}$ & 8 & 4 & 4 \\
\hline 8 & IDBI Bank & 12 & 10 & 4 \\
\hline 9 & $\begin{array}{l}\text { Indus Ind } \\
\text { Bank }\end{array}$ & 12 & 7 & 3 \\
\hline & \multicolumn{2}{|l|}{} \\
\hline
\end{tabular}

Source: primary source

\section{Techniques Used}

Both weighted average score and Mean Score Relative Importance (MSRI) scale (Alam, 1986)

have been used to measure the importance of reasons for leaving a job.

Weighted Average Formula is:

$\left.X=\left(X_{1} W_{1}+X_{2} W_{2}+\ldots . .+X n W n\right) / W_{1}+W_{2}+\ldots W_{n}\right)$

$X=$ Average points

$\mathrm{n}=$ Number of factors

$w=$ Weight for each factors

$\mathrm{X} 1, \mathrm{X} 2, \mathrm{Xn}=$ factors

The formula for calculating MSRI is:

$M S R I=\left\{\sum w+(x-f) n\right\} / N$

$\mathrm{W}=$ weight given to each rank

$\mathrm{n}=$ Number of factors

$\mathrm{N}=$ Number of respondents

$f=$ frequency of responses

\section{FINDINGS AND ANALYSIS}

The results in the table-3 reveal that in general Organisation Politics \& job recognition has been rated as the most important factor and desire to return to school is the least important factor for leaving from an organization. The other eight items have been assigned in between the two positions (Table-3). Easy availability of equal or better paying jobs is second perceived important factor to the employees. Unhappiness with job demands/requirements and friction/conflict with supervisor or co-worker have got the same score as perceived importantfactor for switching (Table-3).
Table 3. Importance of Reasons for Leaving a Job:

\begin{tabular}{|c|c|c|c|}
\hline $\begin{array}{l}\text { S.N } \\
0\end{array}$ & $\begin{array}{l}\text { Importance of Reasons for } \\
\text { Leaving a Job }\end{array}$ & WAS* & MSRI \\
\hline 1 & Politics in Workplace & 6.68 & 4.82 \\
\hline 2 & $\begin{array}{l}\text { Work goes unrecognized/ } \\
\text { unappreciated }\end{array}$ & 6.48 & 4.74 \\
\hline 3 & Little chance to move ahead & 4.94 & 6.22 \\
\hline 4 & $\begin{array}{l}\text { Unhappiness with } \\
\text { demands/requirements }\end{array}$ & 6.00 & 5.20 \\
\hline 5 & Friction with supervisor or coworker & 6.00 & 5.20 \\
\hline 6 & $\begin{array}{l}\text { Disliked management } \\
\text { supervisory style }\end{array}$ & 5.98 & 5.32 \\
\hline 7 & $\begin{array}{l}\text { Dissatisfaction with company } \\
\text { policies }\end{array}$ & 5.74 & 5.64 \\
\hline 8 & $\begin{array}{l}\text { Availability of better training/career } \\
\text { opportunities }\end{array}$ & 5.06 & 6.18 \\
\hline 9 & $\begin{array}{l}\text { Desire to return to school (further } \\
\text { education) }\end{array}$ & 3.47 & 7.68 \\
\hline 10 & $\begin{array}{l}\text { Easy availability of equal or better } \\
\text { paying jobs. }\end{array}$ & 6.43 & 5.00 \\
\hline
\end{tabular}

ö Weighted Average Score

Source: primary source

Both weighted average and MSRI show the same importance ranking of factors leaving a job

Table 4. Importance of Reasons for Leaving a Job (Ranking):

\begin{tabular}{|c|c|c|c|}
\hline S.No & $\begin{array}{l}\text { Importance of Reasons for Leaving } \\
\text { a Job }\end{array}$ & WAS $^{*}$ & MSRI \\
\hline 1 & Politics in Workplace & 1 & 1 \\
\hline 2 & $\begin{array}{l}\text { Work goes unrecognized/ } \\
\text { unappreciated }\end{array}$ & 1 & 3 \\
\hline 3 & Little chance to move ahead & 9 & 9 \\
\hline 4 & $\begin{array}{l}\text { Unhappiness with job } \\
\text { demands/requirements }\end{array}$ & 3 & 3 \\
\hline 5 & Friction with supervisor or coworker & 4 & 4 \\
\hline 6 & $\begin{array}{l}\text { Disliked management or supervisory } \\
\text { style }\end{array}$ & 5 & 5 \\
\hline 7 & Dissatisfaction with company policies & 6 & 6 \\
\hline 8 & $\begin{array}{l}\text { Availability of better training/career } \\
\text { opportunities }\end{array}$ & 8 & 8 \\
\hline 9 & $\begin{array}{l}\text { Desire to return to school (further } \\
\text { education) }\end{array}$ & 10 & 10 \\
\hline 10 & $\begin{array}{l}\text { Easy availability of equal or better } \\
\text { paying jobs. }\end{array}$ & 2 & 2 \\
\hline
\end{tabular}

Source: primary source, MSRI-Mean Score Relative Importance 
Table 5. Management Level wise Ranking of Importance of Reasons for Leaving a Job (MSRI):

\begin{tabular}{|l|l|l|l|l|}
\hline S.No & Importance of Reasons for Leaving a Job & TOP & MID & ENTRY \\
\hline $\mathbf{1}$ & Politics in Workplace & 1 & 3 & 3 \\
\hline $\mathbf{2}$ & Work goes unrecognized/ unappreciated & 2 & 8 & 9 \\
\hline $\mathbf{3}$ & Little chance to move ahead & 5 & 9 & 7 \\
\hline $\mathbf{4}$ & Unhappiness with job demands/requirements & 6 & 1 & 6 \\
\hline $\mathbf{5}$ & Friction with supervisor or coworker & 4 & 5 & 4 \\
\hline $\mathbf{6}$ & Disliked management or supervisory style & 3 & 7 & 5 \\
\hline $\mathbf{7}$ & Dissatisfaction with company policies & 8 & 6 & 2 \\
\hline $\mathbf{8}$ & Availability of better training/career opportunities & 7 & 4 & 10 \\
\hline $\mathbf{9}$ & Desire to return to school (further education) & 10 & 10 & 8 \\
\hline $\mathbf{1 0}$ & Easy availability of equal or better paying jobs. & 9 & 2 & 1 \\
\hline
\end{tabular}

Source: primary source

Unhappiness with job demands/requirements has been rated as the most important factor by midlevel of management and easy availability of equal or better paying jobs has been rated as the most important factor by entrylevel of management (Table-5). Whereas Organisation Politics has been rated as the most important factor by top level of management. On the other hand, desire to return to school is the least important factor to top level and mid-level of management, whereas availability of better training/career opportunities has been rated as the least important factor to entry-level of management (Table-5).

Most companies find that employee departure is reduced when they address issues that affect overall company morale. The respondents were presented with 11 reasons for staying with the current organization and asked to describe their level of agreement or disagreement with these reasons. Mostly agreed that Politics-free environment, career growth, learning and development; exciting work and challenge and recognition for work well done are the reasons for which they are staying with the organization, whereas "family friendly"; "flexibility in work hours and dress code" are the least agreed reasons (Table-6).

Table 6. Reasons to Work with the Organizations (Percentage of Respondents):

\begin{tabular}{|l|l|l|}
\hline S.no & $\begin{array}{l}\text { Reasons to work with this } \\
\text { Organization }\end{array}$ & $\begin{array}{l}\text { A and } \\
\text { SA }\end{array}$ \\
\hline 1 & Politics free work environment & 92 \\
\hline 2 & $\begin{array}{l}\text { Career growth, learning and } \\
\text { development }\end{array}$ & 88 \\
\hline 3 & $\begin{array}{l}\text { Pride in organization, its mission and } \\
\text { quality of product }\end{array}$ & 74 \\
\hline 4 & Exciting work and challenge & 88 \\
\hline 5 & Inspiring leadership & 76 \\
\hline 6 & Fair pay and benefits & 66 \\
\hline 7 & Family-friendly & 34 \\
\hline 8 & Recognition for work well done & 80 \\
\hline 9 & $\begin{array}{l}\text { Autonomy, sense of control over my } \\
\text { work Location }\end{array}$ & 78 \\
\hline 10 & Job security & 64 \\
\hline 11 & Flexibility-dress code, location, etc & 54 \\
\hline
\end{tabular}

Source: primary source,

\section{$A=$ Agree or $S A=S$ trongly Agree}

People want to work in a politics free place where they can succeed and feel their contribution is appreciated. They want to work in great work environment. The absence of this environment can push people to explore other opportunities. Organizations need employees connected to their mission and focused on delivering their products or services as efficiently and effectively as possible. From this research it has been found that now bankers give less importance to location, job security, flexibility - in terms of work hours and dress code (Table7).

Table 7.Management Level Wise Reasons to Work with the Organizations (Percentage of Respondents, Agree or Strongly Agree):

\begin{tabular}{|l|l|l|l|l|}
\hline S.NO & \multicolumn{1}{|c|}{$\begin{array}{c}\text { Reasons to work with } \\
\text { this Organization }\end{array}$} & TOP & MID & ENTRY \\
\hline 1 & Politics free work environment & 100.00 & 88.00 & 86.00 \\
\hline 2 & $\begin{array}{l}\text { Career growth, learning and } \\
\text { development }\end{array}$ & 98.00 & 83.33 & 88.00 \\
\hline 3 & $\begin{array}{l}\text { Pride in organization, its } \\
\text { mission and quality of product }\end{array}$ & 61.90 & 79.63 & 72.00 \\
\hline 4 & Exciting work and challenge & 100.00 & 85.19 & 84.00 \\
\hline 5 & Inspiring leadership & 61.90 & 81.48 & 76.00 \\
\hline 6 & Fair pay and benefits & 61.90 & 75.93 & 48.00 \\
\hline 7 & Family-friendly & 28.57 & 44.44 & 16.00 \\
\hline 8 & Recognition for work well done & 71.43 & 88.89 & 68.00 \\
\hline 9 & $\begin{array}{l}\text { Autonomy, sense of control over } \\
\text { my work Location }\end{array}$ & 71.43 & 87.04 & 64.00 \\
\hline 10 & Job security & 80.95 & 72.22 & 32.00 \\
\hline 11 & $\begin{array}{l}\text { Flexibility-dress code, } \\
\text { location, etc }\end{array}$ & 42.86 & 70.37 & 28.00 \\
\hline
\end{tabular}

\section{CONCLUSIONS AND RECOMMENDATIONS}

Employee termination/leaving can hurt the overall productivity of an organization and is often a symptom of other difficulties. Some employment leaving comes quickly and as a surprise to both the employees and employer. When there are multiple causes for leaving, one is predominant. Turnover is mainly a symptom of other problems, especially dissatisfaction with work or working conditions. Measures taken to prevent turnover are bound to improve other operating results as well. Turnover is costly in terms of time and effort required to recruit, select, and train new personnel. To avoid turnover, organizations may develop some strategy.

The most important factor that makes the employees leave an organization is politics. Though politics in work environment is inevitable the organization can take steps to convert in a positive sense such that employees are not badly affected by it. 
It has been found that employees perceived that another important reason they leave is because their work is unappreciated and not recognized. So, organizations can improve in this area, regardless of the external labour market.

Organizations should emphasize on career growth, learning and development. Organizations need to hire the right people at the right place at the right time and continue to develop their careers. Organizations need to have an ongoing career development program, or skills training program. An investment in upgrading the workforce is one of the best investments a company can make when looking at long-term growth. Hiring the people that are a good "fit" with the culture of the organization-meaning that their values, principles, ethics, and goals (subjective and objective) clearly match those of the company-and then training as necessary will go a long way toward ensuring employee loyalty and retention. Organization should also provide thorough orientation to help employees avoid feeling overwhelmed.

Employees also like exciting and challenging work. They also want recognition for work well done. So, organizations should design their work/assignment in that fashion that employees feel challenging and get recognition after work done in effective and efficient way.

Organizations should focus on fair pay and benefits. Creativity in compensation and benefits can make quite a difference to the welfare of the employee. A company should assess overall employee needs when addressing retention issues. Organization should hire employees from within if possible. Attempt to avoid bringing new people on board at a higher rate than current employees.

Organizations should focus on company policies. It should comply with other organization within the industry. Again it should comply with national and international standard.

Last of all, organization should focus more on employee retention strategies regardless of pay levels. For a company to develop a retention strategy, several steps must be taken. They must assess the current situation and measure the turnover rate in their company. Organizations may create positions such as manager of recruiting and retention, rather than only recruitment to emphasize the importance of getting and then keeping high-quality staff. Organization can built a comprehensive retention management program to get accurate information about why people leave. In the absence of such information, wrong conclusion may be drawn about the causes of departure. Organizations can do it by exit interviews and organization surveys. Human resource professionals, not by employee's immediate superior may conduct exit interview. Tactful questioning may be needed to determine the real reason for quitting. Organizations also design as written "pre-exit interviews," asking questions about why employees would consider leaving, what parts of their job are most frustrating or disappointing, or, more positively, why they stay. However, presences of all factors positive to employee retention do not necessary ensure quality or quantity of work or low turnover rate. Rather ensure more retention, less turnover and after all expected politics-free healthy work environment.

\section{Appendix-l: Questionnaire}

\section{Human Resource Management}

\section{Views of Manager and Employees}

Type of the Organization:

Name of the Organization:

(If you don't have any problem to mention the name of the organization)

No. of total employees:

\section{Demographic Profile of the Employees:}

\begin{tabular}{|l|l|}
\hline Management Level & Positions \\
\hline Top & \\
\hline Mid & \\
\hline Entry & \\
\hline
\end{tabular}

Gender: Male $\square /$ Female

Age: $21-30 \square, 31-40 \square, 41-50 \square, 51$ and above $\square$

Years of Schooling:

Years of Total Work Experience:

Instructions: Would you please rank (1-10) the following most important to least important as reasons for leaving a Job in general? (No 1 will be considered as most important)

\begin{tabular}{|l|l|l|}
\hline S.No & \multicolumn{1}{|l|}{ Importance of Reasons for Leaving a Job } & Ranking \\
\hline $\mathbf{1}$ & Politics in Workplace & \\
\hline $\mathbf{2}$ & Work goes unrecognized/ unappreciated & \\
\hline $\mathbf{3}$ & Little chance to move ahead & \\
\hline $\mathbf{4}$ & Unhappiness with job demands/requirements & \\
\hline $\mathbf{5}$ & Friction with supervisor or coworker & \\
\hline $\mathbf{6}$ & Disliked management or supervisory style & \\
\hline $\mathbf{7}$ & Dissatisfaction with company policies & \\
\hline $\mathbf{8}$ & Availability of better training/career opportunities & \\
\hline $\mathbf{9}$ & Desire to return to school (further education) & \\
\hline $\mathbf{1 0}$ & Easy availability of equal or better paying jobs. & \\
\hline
\end{tabular}


Instructions: Would you please specify the reasons why you like to work with this present organization?

Note: You can specify other reasons you think important.

\begin{tabular}{|l|l|l|l|l|l|l|}
\hline S.NO & \multicolumn{1}{|c|}{$\begin{array}{c}\text { Reasons to work with this } \\
\text { Organization }\end{array}$} & SD & D & N & A & SA \\
\hline 1 & Politics free work environment & & & & & \\
\hline 2 & $\begin{array}{l}\text { Career growth, learning and } \\
\text { development }\end{array}$ & & & & & \\
\hline 3 & $\begin{array}{l}\text { Pride in organization, its mission } \\
\text { and quality of product }\end{array}$ & & & & & \\
\hline 4 & Exciting work and challenge & & & & & \\
\hline 5 & Inspiring leadership & & & & & \\
\hline 6 & Fair pay and benefits & & & & & \\
\hline 7 & Family-friendly & & & & & \\
\hline 8 & Recognition for work well done & & & & & \\
\hline 9 & $\begin{array}{l}\text { Autonomy, sense of control over } \\
\text { my work Location }\end{array}$ & & & & & \\
\hline 10 & Job security & & & & & \\
\hline 11 & Flexibility-dress code, location, etc & & & & & \\
\hline
\end{tabular}

\section{SD D N A SA}

Note: SD: Strongly disagree, D: Disagree, N: Neutral, A: Agree, SA: Strongly Agree.

\# Does your organization have any formal program for preventing organization Politics?

Yes $\square$ No

\# Does your company have any positions such as "Manager of Recruiting and Retention"?

Yes $\square$ No

Thank you.

\section{ACKNOWLEDGEMENT}

Place acknowledgments at the end of the text, before the references.

\section{REFERENCES}

[1] A. F. Kashem, M. Abul, S. M Ullah: "Performance Dynamics of Banking Industry in Chennai" IBS Business Review, Journal of Chennai Institute of Development Studies, Volume: III (2005).

[2] A. I. Kraut, L. M. Saari: Organizaional Surveys: Coming of Age in a new Era, Evolving Practices in Human Resources Management, pp. 302327(1999).

[3] B. Malcolm, C. Jonathan: The Manpower Planning Handbook, pp.19-21, UK: McGraw-Hill (1984).

[4] Branham, F. Leigh. Six Truths about Employee Turnover (1997) http://www.amanet.org/books/ catalog/081440 5975_s.htm. Accessed on 20.04.07.
[5] Cascio, W.F: Costing of Human Resources: The Financial Impact of Behavior in Organizations, Boston: PWS-Kent (1991).

[6] A. D. Decenzo, S. P. Robbins: Human Resource Management, John Wiley \& Sons, Inc., 6th ed., pp. 15-16. (1999)

[7] F. D. Cynthia, S. F. Lyle, S. B. James: Human Resource Management, Houghton Mifflin Co., 5th ed., pp. 754-757. (2004)

[8] K. Beverly, S. J. Evans: Love 'Em or Lose 'Em: Getting Good People to Stay, San Francisco: Berre Koehler, (1999)

[9] Mayes and Allen (1977) 'The sources of bullying psychological work environment and organizational climate', European Journal of Work and Organizational Psychology, Vol. 5, No. 2, pp. 203214.

[10] Padgaonkar A: Gaining Deeper Insights into Employee Retention and Engagement, http://www.refresher.com/abpengage.html,

[11] R.D. Pahik, D.D. Pestonjee: "Organizational Politics orientation as Related to Job satisfaction, Job Involvement and job Anxiety among Research and Development personnel". South Asian Journal of Management (1997).

[12] P. S. Robbins: Organizational behavior, India: Prentice-hall , 8th ed., pp.185. (1999)

[13] J.E. Sheridan: "A Catastrophe Model of Employee Withdrawal Leading to Low Job Performance, High Absenteeism, and Job Turnover During the First Year of Employment" Academy of management Journal, Vol.28, pp.88-109 (1985).

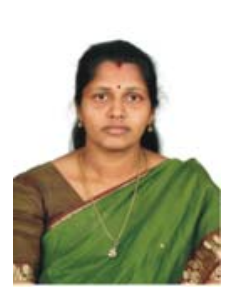

K.R.Sowmya, Assistant Professor in Department of Management Studies, Easwari Engineering College, Ramapuram, Chennai, has 8 years of teaching experience. Currently she is pursuing her Ph.D. in Bharathiyar University. Her areas of interests are Human Resources Management and Organisation Behaviour. She has organized several workshops on Training and Development at has presented several papers in International/ National conferences. 